\title{
Commentary: All things have their season-Timing of regenerative treatment
}

\author{
Ari A. Mennander, $\mathrm{MD}, \mathrm{PhD}$
}

From Tampere University Heart Hospital and Tampere University, Tampere, Finland.

Disclosures: Author has nothing to disclose with regard to commercial support.

Received for publication June 16, 2019; accepted for publication June 17, 2019; available ahead of print July 29, 2019

Address for reprints: Ari A. Mennander, MD, PhD, Tampere University Heart Hospital, SDSKIR, PL 2000, Tampere, Finland (E-mail: ari.mennander@sydansairaala.fi).

J Thorac Cardiovasc Surg 2020;159:1838-9

$0022-5223 / \$ 36.00$

Copyright (c) 2019 by The American Association for Thoracic Surgery

https://doi.org/10.1016/j.jtcvs.2019.06.069

The ischemic heart is prone to cell death and sequential phases of inflammation with eventual fibrosis that contribute to scar formation, thinning of the myocardium, and loss of myocardial contraction. ${ }^{1}$ Many experimental projects have investigated myocardial salvage during ischemia through cellular regeneration and proliferation, but often the most promising means of treatment need to be applied simultaneously with the onset of ischemia. ${ }^{2}$

The study in this issue of the Journal by Chung and colleagues ${ }^{3}$ demonstrates that extracellular vesicles derived from endothelial progenitor cells incorporated within a gel mixture containing hyaluronic acid interfere with the remodeling of myocardial infarction. The endothelial progenitor cell was previously found effective for cellular regeneration, and a part of the cell, namely the vesicle, was dissected apart from the cell and found to have similar healing properties to the endothelial progenitor cell itself. ${ }^{4}$ The extracellular vesicles simulate the beneficial effects observed in the endothelial progenitor cells themselves, because the vesicles carry various RNA species, proteins, and bioactive lipids. ${ }^{3}$ First, endothelial progenitor cells were procured from rats. Second, extracellular vesicles were isolated from these endothelial cells. Meanwhile, a carrying gel to aid in delivering the extracellular vesicles was manufactured with hyaluronic acid. In the in vitro phase of the study, the extracellular vesicles were labeled and applied to human endothelial cells under hypoxia. In the in vivo rat set up, the extracellular vesicles with and without the gel were injected into the penumbral area of a myocardial infarction.

There are several exciting details in this experimental study. The permanent occlusion of a well-defined coronary artery prevents early antegrade reperfusion of the infarction area, which would have blurred the interpretation of the results. The incorporation of the vesicles to endothelial cells is increased under constant hypoxia. Hemodynamic measures were obtained 4 weeks after treatment, when pragmatically, it is important to investigate the effect of the treatment. Histologic analysis was performed to detect the fibrosis and

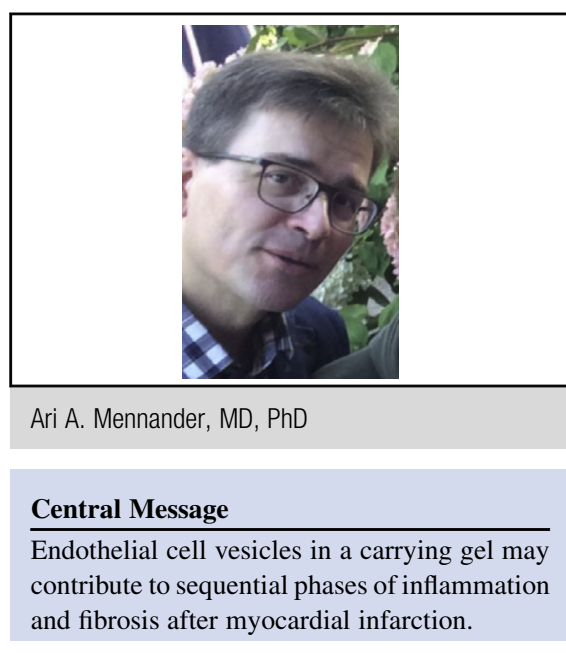

See Article page 1825 .

scar formation that enforces the thinning of the myocardial infarction. When the treatment was applied precisely at day 4 after myocardial infarction, preservation of ventricular size and increased scar thickness were observed.

But why take all this trouble back and forth with dissecting cells and applying a carrying gel? Why not simply add the endothelial progenitor cell, including its vesicles, straight to the ischemic area? The answer may lie in the fear of arrhythmias during excessive scar formation, and in induction of tumor growth while implanting whole cells that may not adapt to the penumbral area. ${ }^{5}$ Nevertheless, immunologic and paracrine effects are to be carefully investigated even when injecting small particles, such as extracellular vesicles, within the myocardium.

Myocardial infarction leads to a chronic insult area with various phases of hypoxia and inflammation. Clinically, treatment may not be initiated simultaneously with the onset of infarction. Proper intervention is time dependent, and what prevents ischemia may not necessarily work for regeneration. The next hurdle in treating myocardial infarction consists of eliminating the need for surgical intervention at any time, which, ironically, is the ultimate aim of any surgical research.

\section{References}

1. Bacmeister L, Schwarzl M, Warnke S, Stoffers B, Blankenberg S, Westermann D et al. Inflammation and fibrosis in murine models of heart failure. Basic Res Cardiol. 2019;18:19.

2. Heusch G. Critical issues for the translation of cardioprotection. Circ Res. 2017; 28:1477-86. 
3. Chung JJ, Han J, Wang LL, Arisi MF, Zaman S, Gordon J, et al. Delayed delivery of endothelial progenitor cell-derived extracellular vesicles via shear thinning gel improves postinfarct hemodynamics. J Thorac Cardiovasc Surg. 2020;159: 1825-35.e2.

4. Chen CW, Wang LL, Zaman S, Gordon J, Arisi MF, Venkataraman CM, et al. Sustained release of endothelial progenitor cell-derived extracellular vesicles from shear-thinning hydrogels improves angiogenesis and promotes function after myocardial infarction. Cardiovasc Res. 2018;1: $1029-40$.

5. Francis Stuart SD, De Jesus NM, Lindsy ML, Ripplinger CM. The crossroads of inflammation, fibrosis, and arrhythmia following myocardial infarction. J Mol Cell Cardiol. 2016;91:114-22. 